\title{
Improving entrepreneurial research methodology: When research design fails
}

\author{
Autumn S. O'Connor ${ }^{\mathrm{a}}$ and Vicki Hutton ${ }^{\mathrm{a}}$
}

The diverse endeavours undertaken by entrepreneurs have the potential to positively impact communities, and yet this population appears notoriously difficult to recruit for research. This paper reflects on declining research participation, particularly noted in top executives and the entrepreneurial community; and introduces a Master's dissertation study which failed to recruit significant numbers of entrepreneurs for quantitative research purposes. While 'failed' research may lack allure, it does provide valuable learning insights for students undertaking new research projects. Quite apart from not repeating past mistakes, outlining research challenges may assist students to develop more creative and robust projects. As such, this paper highlights two significant points regarding barriers to recruiting amongst entrepreneurs. First, we present evidence that entrepreneurs are often over-worked and time poor, and this impacts on their research participation; secondly, we highlight how entrepreneurs respond differently to research activities, and hereby, we offer some recommendations for improved research design.

Keywords: Entrepreneurs; sampling hard-to-reach populations; response rates; recruitment; student research; failure

\section{Introduction}

Entrepreneurs have the potential to transform our global community for the better. The diverse endeavours undertaken by this important population group can add value to local economies, improve standards of living, support social change, and empower the disenfranchised (Gittell, Sohl \& Tebaldi, 2014; Khayesi, George \& Antonakis, 2004; Delfmann \& Koster, 2016). Small businesses and entrepreneurial startups enrich local communities through increasing employment opportunities, with small business contributing to the largest share of total employment in Australia and the US (Gilfillan, 2015; SBA, 2015). These ventures also introduce a demand for unique products and services, and instill community confidence, especially at times of recession (McKeever, Anderson \& Jack, 2014; Koltai \& Muspratt, 2016; Smith, 2016). While the creation of new business ventures positively impacts communities, a problem remains: many new businesses fail within the first five years of operation, and those that do continue, do not grow (ABS, 2012; Decker, Haltiwanger, Jarmin \& Miranda, 2014). Ucbasaran, Shepherd, Lockett \& Lyon (2013) explain entrepreneurial failures tend to have an industry-focus: many new ventures spring forth in technological fields, which by their innovative nature are high-risk; that is, "Where there is uncertainty, there is bound to be failure" (p. 163). Though some businesses fail due to misreading the market, or customer 'readiness' to receive new concepts and technologies, other studies pose that an individual's psychological characteristics may play a greater role in their failed enterprise (Hyytinen, Pajarinen \& Rouvinen, 2015; Artinger \& Powell, 2016). For example, the role of psychological capital, defined by Luthans Avolio, Avey \& Norman (2007) as "an individual's positive psychological state of development" (p. 388), has shown some correlations with venture growth (Drnovšek, Patel \& Cardon, 2012).

Considering the creation and maintenance of a viable business presents several challenges for entrepreneurs, and yet successful ventures have the potential to greatly improve local economy, it seems logical that this population group merits additional research and support. Unfortunately, there is some evidence that the demands of establishing a new business leaves entrepreneurs with little, if any, time and motivation to participate in research projects.

\section{Background}

Declining response rates in research has been noted since the early nineties. Though Kreuter (2013) explains response rates can be increased by offering incentives and using a large budget to drive recruitment, these methods can impact data validity. The alternate, however (low or nonresponse), also raises questions around data quality and challenges around extrapolating upon released study results (Massey, Tourangeau \& Peytchev (2012). After an extensive metaanalysis of 2,037 surveys, covering 1,251,651 individual respondents from organizational studies conducted between 1998-2008, Anseel, Lievens, Schollaert \& Choragwicka (2010) concluded that response rates are decreasing across all organizational groups. Non-working cohorts and junior staff members were more likely to participate in research than senior staff, and top executives had the lowest response rate across all data sets (Anseel et al., 2010). Walker, Redmond, Webster \& Le Clus (2007) explain executives tend to perceive their workload as substantial, and thus may view research participation as unimportant, unless it specifically relates to their business interests. While an emphasis on salience can prove beneficial to lead and grow an enterprise, such a laserfocus may result in missed opportunities and overextending. Indeed, a main concern for entrepreneurs is 'workaholism', and with it, a belief that spending all one's time and energy on one's business will advance the business (Oates, 1971; Burke, 2006; de Mol, Ho \& Pollack, 2016). Furthermore, in a recent study into the challenges of entrepreneurial activity, Lechat \& Torrès (2016) found participants self-rated the stressor 'overwork' as most commonly experienced and, they noted, overwork was largely self-imposed. Lyons (2017) concurs, noting key entrepreneurial education and popularized media also encourages workaholism. This obsessive tendency hails the dark side of entrepreneurship, where excessive and obsessive passion leads to emotional burnout (Fernet, Torrès, Austin \& St-Pierre, 2016). Studies by Fisher, Maritz and Lobo (2013) and Baron, Franklin \& Hmieleski (2013) showed obsessive entrepreneurs were more productive, but their mental health may be adversely affected where their passion

a. School of Counselling, Australian College of Applied Psychology, Melbourne, Victoria, Australia

Author Correspondence: autumn1psych@gmail.com; Vicki.Hutton@acap.edu.au 
is too intense (Baron, Mueller \& Wolfe, 2016). Allen (2015) notes, successful entrepreneurs display inclinations toward task-orientation and single-mindedness, though this must be tempered with a grounded approach, to avoid tunnel-vision. Such studies may glean insight into the entrepreneurial mindset. It seems the nature of being an entrepreneur lends itself to, whether actual or perceived, considerable stress and overwork. As such, this highlights two issues which we will present in this paper: 1) Entrepreneurs are a hard-to-reach population, requiring specific research design; 2) Entrepreneurs face a range of challenges, both external and self-created, and thus can benefit from research and additional support.

The following study reflects on the difficulties of recruiting amongst this elusive population group. Based on the recruitment experience presented following, recommendations for future practice are discussed.

\section{Project Description}

Project overview: What was planned.

The project presented here is part of a Master's dissertation study, undertaken in 2016. The scope for the research project was one year, although this project received a six-month extension to address recruitment issues. Noting the challenges of creating and maintaining a successful enterprise, this study sought to investigate the relationship between subjective perceptions of success and positive psychological traits among Melbourne start-up entrepreneurs. Many empirical studies show noteworthy correlations between positive psychology and business success (Avey, Luthans \& Youssef, 2010; Drnovšek et al., 2012; Juhdi, H., Hamid, Rizal \& Juhdi, N, 2015). However, in the literature, success is defined by researchers and economists, as an objective financial experience (Headd, 2003; Thompson, 2005; Cassar, 2007; McKenzie, Ugbah \& Smothers, 2007). Thus, the aim of the present study was to understand entrepreneurs' own personal perceptions of success; to understand their motivations for start-up, and to explore the psychological traits associated with these subjective feelings. Survey design consisted of a short questionnaire (designed by the first named author), the Psychological Capital Questionnaire (Luthans et al., 2007), and demographics questions were also posed. The survey was professionally designed by a psychological assessments research company, and administered online through their secure computer system. Respondents were advised the survey was anonymous and voluntary, and ethics approval was received prior to data collection. Results from aforementioned study while yielding interesting findings, are not presented in this paper, however we explore the challenges of recruitment and present recommendations for improved research design.

\section{Recruitment overview: What happened.}

The initial strategy involved contacting Melbourne startup entrepreneurs through a trusted network. Participants were drawn from a pool of over 2000 entrepreneurs associated with a large Melbourne consulting firm. Addressing ethical issues regarding privacy, a senior consultant at the firm agreed to act as an intermediary between the researcher and the participants. In April 2016, the senior consultant contacted all entrepreneurs through the firm's mailing list (email), which invited research participation. In the first week after the emails were delivered, the senior consultant made follow-up phone calls to twenty-five entrepreneurs on the mailing list who had previously expressed a significant interest in research. These entrepreneurs were noted by the senior consultant as "having influence" in the community. It was supposed, therefore, that these entrepreneurs would promote the research through word of mouth. However, two and a half months after this first wave of recruitment, there were 19 responses, but only two survey completions. Ethics approval was sought to extend recruitment through social media applications, Instagram and Facebook. From June 2016 to September 2016, the second wave of recruitment involved social media to promote the survey and raise awareness about the importance and relevance of this research to Melbourne entrepreneurs. On Instagram, a total of 32 images ( 1 business strategy, 20 business quotes, 6 inspirational imagery, 5 survey-specific promotional images) were posted containing information about the survey, using topic-relevant hashtags (for example: entrepreneur, success, research). Imagery with quotes attracted the most attention, with the highest likes on the last posted item in September 2016 (quote image, 72 likes and 8 comments). Comments were predominantly positive emoticons (smileys, thumbs-up) and written expressions such as, "great work" or "good job". Also from June 2016, a Facebook research page was created with notes on project description, frequently asked questions, and a link to the survey. Posts within the Facebook research page were 'boosted' and targeted using Facebook analytics to reach Melbourne users who like entrepreneurial pages. An invitation to participate in research was also posted to various Facebook groups and pages identified as having reach with Melbourne entrepreneurs. A total of 40 Facebook groups were contacted regarding this study. Of the 40 contacted, 12 Facebook groups accepted membership and allowed a research invitation to be posted on the communal walls. Ten Facebook pages were also contacted, and two agreed to post a research call to their timeline. Although some individuals on Facebook may be a member of two or more groups or pages, the total reach of Facebook posts accounted for 2,909 possible participants to this research study. Reach of Instagram posts was not calculated.

Of the 2,000 entrepreneurs directly contacted in wave one of recruitment, and potential reach of 2,902 entrepreneurs in wave two of the recruitment process, 126 individuals responded, 15 started the survey, 5 were screened out, and only 10 successfully completed it (10 of the 126 respondents; $0.79 \%$ participation rate; see Figure 1 ).

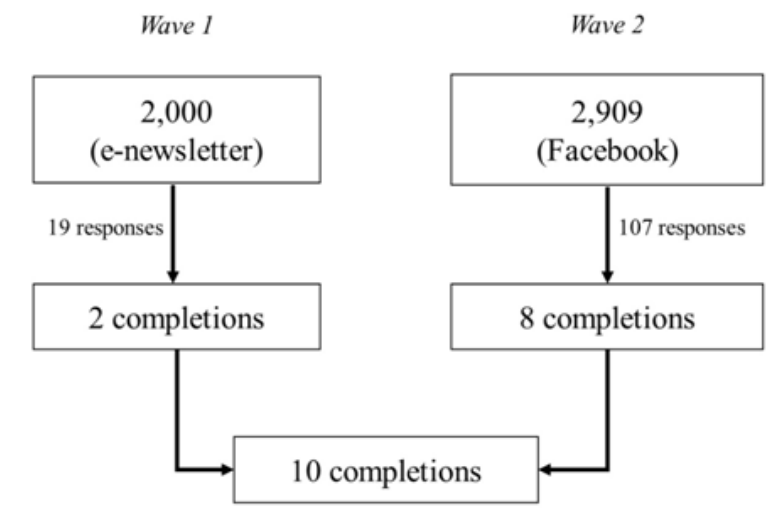

Figure 1. Recruitment waves and response rates. 
Discussion: What this might mean.

Despite two waves of recruitment, participation rate in this study was below $1 \%$. While we note that low participation in the presented Master's project is likely linked to inexperience of the student, we also reflect that entrepreneurs are a hard-to-reach population. The latter is well-supported in the literature on response rates. Supporting this observation is Baron et al.'s (2016) study into psychological capital and entrepreneurial stress, which recorded 167 survey completions after contacting 3000 entrepreneurs, with two follow-up waves. Earlier in this paper, we discussed the increasing decline of response rates across all populations was outlined. Top executives and entrepreneurs were noted as the least likely to participate in research due to their perception of heavy workloads (Anseel et al., 2010). In an exploration of narratives on entrepreneurial identity, Hytti (2003) found participants defined themselves in relation to their busyness: that being busy was akin to being useful, trustworthy and, overwork is expected in the entrepreneurial community; to not be busy would suggest one's venture is amateur. With such an orientation to work-life, we reflect it is quite possible an entrepreneur's worldview will see many ignore valuable projects due to their perceived lack of time.

\section{Recommendations}

This study highlighted the need to re-assess the method of data collection when researching entrepreneurs. Morton, Bandara, Robinson \& Carr (2012) concur, stating a project with low response rates may still prove beneficial and valid if the authors reflect on non-participation and attempt to improve recruitment methodology. Although this project did not gather data on non-participants, our system did show only 15 of 126 respondents continued beyond the survey landing page. It is hypothesized that the research introductory statement may have contained too much information. Future research design may consider concise explanatory statements to reduce the 'respondent-fatigue' potentially associated with lengthy explanations. This problem has previously been identified by Hochheimer et al. (2016). In terms of improving research design, we have developed a series of recommendations to use specifically when recruiting entrepreneurs. Anseel et al (2010) note, while response enhancing techniques are outlined in general texts, different types of respondents require different types of approaches. Bearing this in mind, our recommendations are presented following. We expect combining all three methods may prove most effective in generating greater response rates.

(1) Entrepreneurs want positive and familiar branding first.

Entrepreneurs appear highly focused on how they might be perceived. Whether at start-up stage or improving an established business, Wheeler (2012) explains business leaders must be vigilant in developing their brand identity; aligning themselves with favourable activities and associations. This notion is supported by Kuratko, Ireland, Covin \& Hornsby (2005) who describe entrepreneurs with a "risk orientation", scanning the environment for opportunities and threats to their brand. It is interesting that Cycyota \& Harrison (2006) and Bartholomew \& Smith (2006) explain business leaders are more likely to participate where the research project is associated with a highly respected university, familiar trade association, or well-known person. As such, this suggests entrepreneurs may associate research participation with their own brand identity. In marketing literature, brand recognition encourages greater participation; consumers perceive more favourable outcomes where the engagement involves a wellknown or familiar brand (Huang \& Sarigöllü; 2014). And, furthermore, noting the 'masculine voice' of entrepreneurship and reflecting on a tendency to grandiosity (Brooks, Huang, Kearney \& Murray, 2014; Smith, 2010), it could be beneficial to link research design into a pro-branding male narrative. Although ethically, researchers should, perhaps not play into the politics of business, where a project is associated with a positive brand or person, it is noted that response rates increase.

(2) Entrepreneurs prefer survey delivery in a face-to-face mode

Personally-administered surveys provide a sense of 'psychological ownership' over the responses given (Irvine, Drew \& Sainsbury, 2013) and may provide entrepreneurs greater confidence in the project. Cycyota \& Harrison (2006) state top executives and business leaders are more likely to participate in research projects that reflect their business needs or specific industry focus. By meeting with the participant and delivering surveys in a face-to-face manner, participants can better gauge topic salience. Sekaran \& Bougie (2016) add, in organizational research, the utilization of paper-based surveys, delivered in a face-to-face interaction gives "an almost $100 \%$ response rate" (p344). Whether semistructured interview, focus group, workshop, or a sit down with a paper-based survey, Duncan \& Fiske (2015) state, where the field interviewers are trained and professional, face-to-face interactions with participants increase response rates exponentially. They also reflect face-to-face interactions increases participant confidence through rapport-building.

(3) Entrepreneurs need survey reminders and follow-ups

The literature supports entrepreneurs' tendencies to overwork and remain focused on their own enterprise growth. As such, entrepreneurs and business decision-makers may require more followups to participate in research. Sappleton \& Lourenço (2017) suggest busy-ness may lead to forgetfulness regarding research participation. Torres van Grinsven (2015) notes that reminders encourage participation by highlighting the importance of the research, and a may also create feelings of regret or guilt tied to non-participation. Mellahi \& Harris (2016) concur, noting prenotifications and follow-ups significantly improve response rates across all populations. 
While we acknowledge these three methods may increase response rates in entrepreneurs, we also note foreseeable challenges in implementation. Most notably, ethical dilemmas present around branding and issues of participant anonymity; other drawbacks include a need for increased funding and longer data collection time frames.

\section{Concluding Remarks}

Entrepreneurs have the potential to contribute in large ways to the economy and the community. Though research could certainly benefit this population, the presented Master's project highlighted significant challenges in the recruitment process, leading to a very low response rate. We reflected on existing literature which might explain some difficulties reaching this population, and provided recommendations for improvement to research design. Though we acknowledge student research ability may have contributed to the unfavourable outcome of the project, we also reflect that entrepreneurs experience the world in a very different way to other populations. As such we note while entrepreneurs might hard to reach, they are a necessary to reach population; with the right research design, perhaps we can help empower this population and support the community at large.

\section{Declaration of Conflicting Interests}

The authors declared no potential conflicts of interest with respect to the research, authorship, and/or publication of this article.

\section{Funding}

The authors received no financial support for the research, authorship, and/or publication of this article.

\section{References}

ABS (2012). Small Business: An Economic Overview. Australian Bureau of Statistics, Sydney, NSW, Australia. Retrieved from https://www.rba.gov.au/publications/workshops/oth er/small-bus.../01-overview.pdf/.

Allen, K.R. (2015). Launching new ventures: An entrepreneurial approach. Boston, MA, USA: Nelson Education.

Anseel, F., Lievens, F., Schollaert, E., \& Choragwicka, B. (2010). Response rates in organizational science, 1995-2008: A meta-analytic review and guidelines for survey researchers. Journal of Business and Psychology, 25(3), 335-349.

Artinger, S. \& Powell, T.C. (2016). Entrepreneurial failure: Statistical and psychological explanations. Strategic Management Journal, 37(6), 1047-1064.

Avey, J.B., Luthans, F., \& Youssef, C.M. (2010). The additive value of psychological capital: Predicting positive and negative work attitudes and behaviours. Journal of Management, 36, 430-452.

Baron, R.A., Franklin, R.J., \& Hmieleski, K.M. (2013). Why Entrepreneurs Often Experience Low, Not High, Levels of Stress. The Joint Effects of Selection and Psychological Capital. Journal of Management, 27(5), 742-768.

Baron, R.A., Mueller, B.A., \& Wolfe, M.T. (2016). Selfefficacy and entrepreneurs' adoption of unattainable goals: The restraining effects of self- control. Journal of Business Venturing, 31(1), pp. 55-71.

Bartholomew, S., \& Smith, A. D. (2006). Improving survey response rates from chief executive officers in small firms: The importance of social networks. Entrepreneurship Theory and Practice, 30(1), 83-96.

Brooks, A. W., Huang, L., Kearney, S. W., \& Murray, F. E. (2014). Investors prefer entrepreneurial ventures pitched by attractive men. Proceedings of the National Academy of Sciences, 111(12), 4427-4431.

Burke, R.J. (2006). Work hours and work addiction, in Burke, R.J. (Ed.), Research Companion to Working Time and Work Addiction. Cheltenham, UK: Edward Elgar, pp. 3-35.

Cassar, G. (2007). Money, money, money? A longitudinal investigation of entrepreneur career reasons, growth preferences and achieved growth. Entrepreneurship and Regional Development, 19(1), 89-107.

Cycyota, C.S. \& Harrison, D.A. (2006). What (not) to expect when surveying executives: A meta-analysis of top manager response rates and techniques over time. Organizational Research Methods, 9(2), 133160.

Decker, R., Haltiwanger, J., Jarmin, R., \& Miranda, J. (2014). The role of entrepreneurship in US job creation and economic dynamism. The Journal of Economic Perspectives, 28(3), 3-24.

Delfmann, H. \& Koster, S. (2016). The effect of new business creation on employment growth in regions facing population decline. The Annals of Regional Science, 56(1), 33-54.

Drnovšek, M., Patel, P. C., \& Cardon, M. S. (2012). Entrepreneur's psychological capital and venture growth: testing the goal mediated relationships. Frontiers of Entrepreneurship Research, 32(6), 4.

Duncan, S. \& Fiske, D.W. (2015). Face-to-face interaction: Research, methods, and theory (Vol. 3), New York, NY, USA: Routledge.

Fernet, C., Torrès, O., Austin, S. \& St-Pierre, J. (2016). The psychological costs of owning and managing an SME: Linking job stressors, occupational loneliness, entrepreneurial orientation, and burnout. Burnout Research, 3(2), 45-53.

Fisher, R., Maritz, A., \& Lobo, A. (2013). Obsession in Entrepreneurs-Towards a Conceputalisation. Entrepreneurship Research Journal, 3(2), 207-237.

Gilfillan, G. (2015). Statistical snapshot: small business employment contribution and workplace arrangements. Parliament of Australia: Statistics and Mapping Section, 2 December 2015.

Gittell, R., Sohl, J., \& Tebaldi, E. (2014). Do entrepreneurship and high-tech concentration create jobs? Exploring the growth in employment in US metropolitan areas from 1991 to 2007. Economic Development Quarterly, 28(3), 244-253.

Headd, B. (2003). Redefining Business Success: Distinguishing Between Closure and Failure. Small Business Economics, 21(1), 51-61. 
Hochheimer, C.J., Sabo, R.T., Krist, A.H., Day, T., Cyrus, J., \& Woolf, S.H. (2016). Methods for evaluating respondent attrition in web-based surveys. Journal of medical Internet research [Online], 18(11). Retrieved from http://scholarscompass.vcu.edu/bios_pubs/47/.

Huang, R. \& Sarigöllü, E. (2014). "How brand awareness relates to market outcome, brand equity, and the marketing mix", in Choi, T. (Ed), Fashion Branding and Consumer Behaviors. New York, NY, USA: Springer Publishing. pp. 113-132.

Hytti, U. (2003). Stories of entrepreneurs: Narrative construction of identities. (Doctoral dissertation). University of Turku, Finland. Retrieved from http://www.doria.fi/bitstream/handle/10024/98535/ Ae1_2003hytti.pdf?sequence $=2$

Hyytinen, A., Pajarinen, M., \& Rouvinen, P. (2015). Does innovativeness reduce startup survival rates? Journal of Business Venturing, 30(4), 564-581.

Irvine, A., Drew, P., \& Sainsbury, R. (2013). 'Am I not answering your questions properly?' Clarification, adequacy and responsiveness in semi-structured telephone and face-to-face interviews. Qualitative Research, 13(1), 87-106.

Juhdi, H., Hamid, R.A., Rizal, A.M., \& Juhdi, N. (2015). Psychological Capital and Entrepreneurial Success: A Multiple-Mediated Relationship. European Journal of Interdisciplinary Studies, [S.I.], 2(1), 110-113.

Khayesi, J. N., George, G., \& Antonakis, J. (2014). Kinship in entrepreneur networks: Performance effects of resource assembly in Africa. Entrepreneurship Theory and Practice, 38(6), 1323-1342.

Koltai, S. R. \& Muspratt, M. (2016). Peace Through Entrepreneurship: Investing in a Startup Culture for Security and Development. Washington DC, USA: Brookings Institution Press. Retrieved from http://www.jstor.org/stable/10.7864/j.ctt1dgn6g8.

Kreuter, F. (2013). Facing the nonresponse challenge. The ANNALS of the American Academy of Political and Social Science, 645(1), 23-35.

Kuratko, D.F., Ireland, R.D., Covin, J.G., \& Hornsby, J.S., (2005). A Model of Middle-level Managers' Entrepreneurial Behaviour. Entrepreneurship Theory and Practice, 29(6), 699-716.

Lechat, T. \& Torrès, O. (2016). "Exploring Negative Affect in Entrepreneurial Activity: Effects on Emotional Stress and Contribution to Burnout", in Ashkanasy, N.E., Härtel, C.E.J. and Zerbe, W.J.

(Eds.). Emotions and Organizational Governance. Bingley, UK: Emerald Group Publishing Limited. pp. 69-99.

Luthans F., Avolio, B.J., Avey, J.B., \& Norman, S.M. (2007). Psychological capital: Measurement and relationship with performance and job satisfaction. Personnel Psychology, 60, 541-572.

Lyons, D. (2017, 2-3 September). Working 9 to 5 is for losers. Australian Financial Review. p.xx.

Massey, D.S, Tourangeau, R., \& Peytchev, A. (2012). Consequences of Survey Nonresponse. The ANNALS of the American Academy of Political and
Social Science. 645(1), 88 - 111, doi: $10.1177 / 0002716212461748$.

McKeever, E., Anderson, A., \& Jack, S. (2014). Entrepreneurship and mutuality: social capital in processes and practices. Entrepreneurship and Regional Development, 26(5-6), 453-477.

McKenzie, B., Ugbah, S.D., \& Smothers, N. (2007), "Who Is an Entrepreneur?" Is It Still the Wrong Question. Academy of Entrepreneurship Journal. 13(1), 23-43.

Mellahi, K. \& Harris, L.C. (2016). Response rates in business and management research: An overview of current practice and suggestions for future direction. British Journal of Management, 27(2), 426-437.

de Mol, E., Ho, V.T., \& Pollack, J.M. (2016). Predicting Entrepreneurial Burnout in a Moderated Mediated Model of Job Fit. Journal of Small Business Management (online), doi: 10.1111/jsbm.12275.

Morton, S. M. B., Bandara, D. K., Robinson, E. M. and Carr, P. E. A. (2012). In the $21^{\text {st }}$ Century, what is an acceptable response rate? Australian and New Zealand Journal of Public Health, 36, 106-108. doi:10.1111/j.1753-6405.2012.00854.x

Oates, W. (1971). Confessions of a Workaholic: The Facts About Work Addiction. New York, NY, USA: World Publishing Company.

Sappleton, N., \& Lourenço, F. (2016). Email subject lines and response rates to invitations to participate in a web survey and a face-to-face interview: the sound of silence. International Journal of Social Research Methodology, 19(5), 611-622.

SBA (2015). Small Business Profiles for the States and Territories. U.S. Small Business Administration: Office of Advocacy.

Smith, R. (2010). Masculinity, doxa and the institutionalisation of entrepreneurial identity in the novel Cityboy. International Journal of Gender and Entrepreneurship, 2(1), 27-48.

Thompson, A. (2005). Entrepreneurship and Business Innovation. (Doctoral dissertation). Murdoch University, WA, Australia. Retrieved from https://core.ac.uk/download/pdf/11230992.pdf/

Torres van Grinsven, V. (2015). Motivation in Business Survey Response Behavior: Influencing motivation to improve survey outcome (Doctoral dissertation), Utrecht University, The Netherlands.

Ucbasaran, D., Shepherd, D.A., Lockett, A., \& Lyon, S.J. (2013). Life after business failure: The process and consequences of business failure for entrepreneurs. Journal of Management, 39(1), 163202.

Walker, E., Redmond, J., Webster, B., \& Le Clus, M. (2007). Small business owners: too busy to train?" Journal of Small Business and Enterprise Development, 14(2), 294-306.

Wheeler, A. (2012). Designing brand identity: an essential guide for the whole branding team. John Wiley \& Sons. 